\title{
The Cell Cycle of the Budding Yeast Sterigmatomyces halophilus: Oscillations in the Amounts and Activities of the Terminal Components of the Respiratory Chain
}

\author{
By IAN SALMON† AND ROBERT K. POOLE* \\ Department of Microbiology, Queen Elizabeth College, University of London, Campden Hill, \\ London W8 $7 A H, U . K$.
}

(Received 21 September 1982; revised 29 December 1982)

\begin{abstract}
Cells harvested from exponentially growing cultures of the budding yeast Sterigmatomyces halophilus were fractionated according to their age in the cell cycle by isopycnic-zonal centrifugation in Urografin gradients. Activities of five enzymes were assayed in cell-free extracts, prepared using a French pressure cell. The activities of catalase and three enzymes of the mitochondrial inner membrane (NADH dehydrogenase, succinate dehydrogenase and cytochrome $c$ oxidase) doubled during the cell cycle but showed complex oscillatory patterns. Acid phosphatase activity increased continuously during the cell cycle. Fourth-order finite difference analysis of low-temperature difference spectra showed that the levels of three $b$-type cytochromes increased continuously during the cycle. In contrast, amounts of cytochromes $c_{1}, c$ and $a a_{3}$ oscillated over one cycle, with cytochromes $c$ and $a a_{3}$ rising to two maxima per cycle in phase with cytochrome $c$ oxidase activity. Liganding of redox-active metals, and discontinuous synthesis and proteolysis of apocytochromes are discussed as possible mechanisms for cell cycledependent fluctuations in the composition and function of the respiratory chain.
\end{abstract}

\section{INTRODUCTION}

In the cell cycles of many eukaryotic micro-organisms, the activities of certain enzymes increase discontinuously (for a review, see Lloyd et al., 1982a). It is not clear, however, whether these changes in activities represent actual changes in amounts of enzyme proteins or modulation of their activities. Only a few studies have been made of changes in enzyme amounts during the cell cycle. Because of technical difficulties in quantitatively purifying individual enzymes during the cell cycle, immunological assays have been used. For example, the amount of catalase protein oscillates with a periodicity of about $1 \mathrm{~h}$ so as to give seven maxima per cell cycle in Acanthamoeba castellanii (Edwards et al., 1981). An alternative approach has been to examine the rate of synthesis of individual proteins, revealed by two dimensional electrophoresis, using a dual-label procedure involving long-term and pulse labels. Using this technique, Elliott \& McLaughlin (1978) examined the behaviour of 111 proteins during the cell cycle of Saccharomyces cerevisiae and concluded that they all showed a continuous, exponentially increasing, rate of synthesis. However, these authors considered three classes of proteins to be less well resolved by this method - the very acidic, the very basic, and those of low solubility, such as the membrane-associated proteins of mitochondria. Fortunately, certain proteins in the last class, namely the cytochromes, are directly measurable by spectroscopic examination of intact cells.

The direct determination of cytochrome content has the distinct advantage that no extraction of proteins is necessary and that, in some cases, the spectrally determined quantities may be compared with measurements of functional activity (Poole \& Lloyd, 1974; Poole et al., 1974;

† Present address: Biological Laboratory, The University, Canterbury, Kent CT2 7NJ, U.K. 
Cottrell et al., 1975). The paucity of similar measurements may be due, in part, to (1) the relative insensitivity of the technique (and the consequent necessity for large numbers of cells of one particular age) and (2) the extensive overlap of individual cytochrome absorptions, even at low temperatures, making accurate quantification difficult (Salmon \& Poole, $1980 a$; von Jagow et al., 1973).

In the present study, the activities of three mitochondrial enzymes and the amounts of spectroscopically detectable cytochromes were examined during the cell cycle of the budding yeast Sterigmatomyces halophilus. Additionally, the activities of two marker enzymes (Lloyd \& Cartledge, 1974) for other cellular membraneous systems (catalase for peroxisomes and acid phosphatase for lysosomes) were measured. Sufficient material for such studies was provided by large-scale zonal fractionation of exponentially growing cultures into different density and size classes (Salmon \& Poole, 1983). Fourth-order finite difference analysis of the complex cytochrome spectra was used to resolve and quantify the individual components, some of which accumulate continuously, whilst cytochrome $c$ and its immediate electron acceptor, cytochrome $a a_{3}$, oscillate in phase with cytochrome $c$ oxidase activity.

Parts of this work have been presented previously in abstract form (Salmon \& Poole, 1980 b).

\section{METHODS}

Maintenance, growth and harvesting of the organism. Sterigmatomyces halophilus CBS 4609 was maintained on a solid, complex medium and grown in a defined liquid medium with glucose as the growth-limiting substrate as described previously (Salmon \& Poole, 1980a). Exponentially growing cultures were harvested by passing the culture through an MSE continuous action rotor and resuspending the cells in a small volume of $3 \%(\mathrm{w} / \mathrm{v}) \mathrm{NaCl}$ (Salmon \& Poole, 1983).

Culture fractionation. Fractionation of the cell population into various size classes, representing successive stages in the cell cycle, was by isopycnic-zonal centrifugation through Urografin gradients (Salmon \& Poole, 1983). Fractions were collected, and the cells harvested and washed as described previously (Salmon \& Poole, 1983) and resuspended in $50 \mathrm{mM}$-Tris $/ \mathrm{H}_{2} \mathrm{SO}_{4}$ buffer ( $\mathrm{pH} 7 \cdot 2$ ).

Preparation of cell-free extracts. Cells, resuspended in a small volume ( 5 to $10 \mathrm{ml}$ ) of $50 \mathrm{~mm}-\mathrm{Tris}_{2} / \mathrm{H}_{2} \mathrm{SO}_{4}$ buffer (pH 7.2) were broken by two slow passages through a cold $\left(4^{\circ} \mathrm{C}\right.$ ) French pressure cell (Milner et al., 1950) at $138 \mathrm{MPa}\left(20000 \mathrm{lbf} \mathrm{in}^{-2}\right)$. Unbroken cells and cell wall debris were removed by acceleration to 10000 r.p.m. in the $16 \times 15 \mathrm{ml}$ rotor $\left(8500 \mathrm{~g}, r_{\mathrm{av}} .7 .6 \mathrm{~cm}\right)$ of an MSE 18 centrifuge, followed by immediate deceleration. The supernatant, which was termed the cell-free extract, was carefully decanted to avoid disturbance of the pellet.

Cytochrome spectra and their numerical analyses. Difference spectra at $77 \mathrm{~K}$ and their fourth-order finite difference analyses were obtained exactly as described by Salmon \& Poole $(1980 \mathrm{a})$. Suspensions of cells in $50 \mathrm{~mm}$ Tris $/ \mathrm{H}_{2} \mathrm{SO}_{4}$ buffer (pH 7.2) were reduced with a few grains of $\mathrm{NaBH}_{4}$ or oxidized with $4.5 \mathrm{~mm}-\mathrm{H}_{2} \mathrm{O}_{2}$ before freezing the samples by immersion in liquid nitrogen. To improve signal-to-noise ratios, six successive scans were summed for each spectrum. No baseline corrections were made.

The intensities of the cytochrome $\alpha$-bands in reduced minus oxidized difference spectra of intact $S$. halophilus were directly proportional to cell concentration up to $1.6 \times 10^{10}$ cells $\mathrm{ml}^{-1}$. Above these concentrations, the intensities decreased due to the high non-specific absorption and light scattering of the suspensions. Cell concentrations were, therefore, adjusted to about $1 \times 10^{10}$ cells $\mathrm{ml}^{-1}$ for quantifying cytochromes.

To enable the measured amounts of cytochromes to be tested against a null hypothesis (see below), the reproducibility of the analysis for each absorption maximum was estimated by preparing 10 replicate reduced minus oxidized difference spectra of cells from an exponentially growing culture. For cytochrome $a a_{3}$, the intensity of the peak at $600 \mathrm{~nm}$ was measured and the coefficient of variation calculated (S.D./mean). In the region 530 to $570 \mathrm{~nm}$, the fourth-order finite difference analysis for each spectrum was computed. The mean positions of the revealed absorption maxima and the coefficients of variation in the intensity of each peak were then calculated. The mean peak positions $(\mathrm{nm})$ with their coefficients of variation in intensity (in parentheses) were: $543.5(0 \cdot 17) ; 547.2(0 \cdot 10)$; $551 \cdot 1(0 \cdot 21) ; 554.5(0 \cdot 70) ; 556 \cdot 6(0 \cdot 27) ; 559.8(0 \cdot 10) ; 563 \cdot 1(0.26) ; 600(0 \cdot 10)$. The coefficients of variation in the positions of the absorption maxima were all about $5 \times 10^{-4}$.

Enzyme assays. Preliminary experiments were performed, using a cell-free extract of cells from an exponentially growing culture, to determine the $\mathrm{pH}$ optima of the enzymes and to measure the range over which the rates of enzyme reactions were linear with both time and amount of extract used. The spectrophotometric assays were carried out at room temperature (about $20^{\circ} \mathrm{C}$ ) with a Pye Unicam SP1700 spectrophotometer; acid phosphatase was determined at $25^{\circ} \mathrm{C}$.

The efficiency of breakage of cells in the French pressure cell was variable. To make allowances for this in the calculation of enzyme activities per cell, total protein was measured in samples prior to disruption, and again in the 
cell-free extract. The percentage recovery of protein was calculated and the measured activities corrected to $100 \%$ release of protein (Poole \& Lloyd, 1973). Within individual experiments, the protein recoveries varied little; in three selected examples of cell cycle fractionations the mean values were $50 \cdot 1 \%, 37 \cdot 1 \%$ and $28.5 \%$ and the respective coefficients of variation were $0 \cdot 11,0 \cdot 11$ and $0 \cdot 19$. No reproducible oscillations in protein recovery occurred that could account for the observed fluctuations in enzyme activities (see Results). In a control experiment, the mean protein recovery on 12 replicate samples from an exponential culture was $39 \%$ (coefficient of variation $0 \cdot 15$ ). Enzyme assays were performed on extracts prepared from cell suspensions at several concentrations and the activities per cell calculated. The coefficient of variation of these results represents the maximum variation inherent in the determination of enzyme activity.

The assay for succinate dehydrogenase (succinate:2,6-dichlorophenolindophenol oxidoreductase; EC 1.3.99.1) was based on that of Arrigoni \& Singer (1962). The assay mixture contained, in a final volume of $3 \mathrm{ml}$ : $6.7 \mathrm{~mm}$-sodium succinate, $2.2 \mathrm{~mm}$-phenazine methosulphate, $82 \mu \mathrm{M}$-2,6-dichlorophenolindophenol, $3.27 \mathrm{~mm}$ $\mathrm{KCN}, 100 \mathrm{~mm}$-Tris/ $\mathrm{HCl}$ buffer $\mathrm{pH} \mathrm{7.5}$, and 20 to $100 \mu \mathrm{l}$ of cell-free extract. The order of addition of reagents was extract, succinate (which were incubated together for 5 to $15 \mathrm{~min}$ ), mixture (buffer, cyanide, dichlorophenolindophenol) and (to start) phenazine methosulphate. Prior incubation of the enzyme with substrate activates the enzyme and prevents KCN deactivating it (Singer et al., 1973). Measured rates were independent of the incubation times used. The rate of dye reduction was measured at $600 \mathrm{~nm}$ against that in control reaction mixtures lacking succinate. The coefficient of variation for this assay was 0.12 with nine samples analysed.

Cytochrome $c$ oxidase (ferrocytochrome $c$ :oxygen oxidoreductase; EC 1.9.3.1) activity was measured by following the oxidation of cytochrome $c$ at $550 \mathrm{~nm}$ (Smith, 1955). The assay mixture contained, in a final volume of $1 \mathrm{ml}: 8 \mu \mathrm{M}$-cytochrome $c$ (reduced prior to use with $\mathrm{NaBH}_{4}$ ), $20 \mathrm{~mm}$-potassium phosphate buffer $\mathrm{pH} 6.5$, and 5 to $100 \mu l$ of cell-free extract. The rate of oxidation was measured against controls lacking the cell-free extract. The coefficient of variation for this assay was 0.08 with 10 samples analysed.

Estimation of NADH dehydrogenase (NADH : cytochrome $c$ oxidoreductase; EC 1.6.99.3) activity was based on the method of Mahler (1955). The assay mixture contained, in a final volume of $1 \mathrm{ml}: 175 \mu \mathrm{M}-\mathrm{NADH}, 21 \cdot 5 \mu \mathrm{M}$ cytochrome $c, 10 \mathrm{mM}-\mathrm{KCN}, 16 \mathrm{~mm}$-potassium phosphate buffer $\mathrm{pH} 7 \cdot 0$, and 20 to $100 \mu \mathrm{l}$ of the cell-free extract. The reduction of cytochrome $c$ was followed at $550 \mathrm{~nm}$ against controls lacking NADH. The coefficient of variation for this assay was $0 \cdot 12$ with 10 samples analysed.

Catalase $\left(\mathrm{H}_{2} \mathrm{O}_{2}: \mathrm{H}_{2} \mathrm{O}_{2}\right.$ oxidoreductase; EC 1.11.1.6) activity was assayed by the method of Lück (1963). The assay mixture contained, in a final volume of $3 \mathrm{ml}: 13 \cdot 3 \mathrm{~mm}-\mathrm{H}_{2} \mathrm{O}_{2}, 20 \mathrm{~mm}$-potassium phosphate buffer $\mathrm{pH} 7 \cdot 5$, and 100 to $200 \mu \mathrm{l}$ of cell-free extract. The rate of loss of $\mathrm{H}_{2} \mathrm{O}_{2}$ was measured at $240 \mathrm{~nm}$ against controls lacking the cell-free extract. The coefficient of variation for this assay was $0 \cdot 14$ with 6 samples analysed.

Acid phosphatase [ $o$-phosphoric-monoester phosphohydrolase (acid optimum); EC 3.1.3.2] activity was determined by the method of Torriani (1960). The assay mixture contained, in a final volume of $1 \mathrm{ml}: 5 \mathrm{~mm}-\mathrm{p}$ nitrophenyl phosphate, $0.02 \%(\mathrm{w} / \mathrm{v})$ Triton X-100, $100 \mathrm{mM}$-sodium acetate buffer $\mathrm{pH} 5.0$, and 100 to $200 \mu \mathrm{l}$ of the cell-free extract. The reaction was stopped by the addition of $2 \mathrm{ml} 1 \mathrm{M}-\mathrm{NaOH}$, and the colour that developed at $420 \mathrm{~nm}$ determined against a control lacking the cell-free extract. The coefficient of variation for this assay was $0 \cdot 12$ with 6 samples analysed.

All assays were completed within $10 \mathrm{~h}$ of the preparation of the cell-free extracts. Activities are expressed as amol of substrate transformed $\min ^{-1}$ per cell or as amol of product formed $\min ^{-1}$ per cell.

Protein assay. Protein (typically 0.5 to $1 \mathrm{mg} \mathrm{m}^{-1}$ ) was determined in cell-free extracts by Lowry's method, with BSA as standard. However, Tris buffer interferes in this assay by both decreasing chromophore development and by contributing blank colour (Rej \& Richards, 1974). This interference was overcome by incorporating Tris at the same concentration (1.33 mM) in all the standards as well as samples (Rej \& Richards, 1974).

The total protein content of whole cells was determined as described by Salmon \& Poole (1983). Tris interference was not as marked in this assay, but corrections were made if the final concentration of Tris exceeded $0 \cdot 15 \mathrm{~mm}$. Total protein estimates were carried out in quadruplicate.

Cell counting and sizing. These were performed using a Coulter Counter model $\mathrm{Z}_{\mathrm{BI}}$ fitted with a $50 \mu \mathrm{m}$ aperture probe and Channelyzer C1000 as described by Salmon \& Poole (1983).

Chemicals. Cytochrome $c$ (type III, from horse heart), NADH (Grade III, from yeast), 2,6-dichlorophenolindophenol and $p$-nitrophenyl phosphate were obtained from Sigma. Phenazine methosulphate was from Koch-Light, Urografin 370 was from Schering Chemicals, Burgess Hill RH15 9NE, U.K. and BSA was from Armour Pharmaceuticals, Eastbourne, U.K. General reagents were of analytical grade wherever possible.

\section{RESULTS}

\section{Enzyme activities during the cell cycle}

Using isopycnic sedimentation in Urografin gradients, cells from exponentially growing cultures of $S$. halophilus were separated into homogeneous size classes, representing successive 


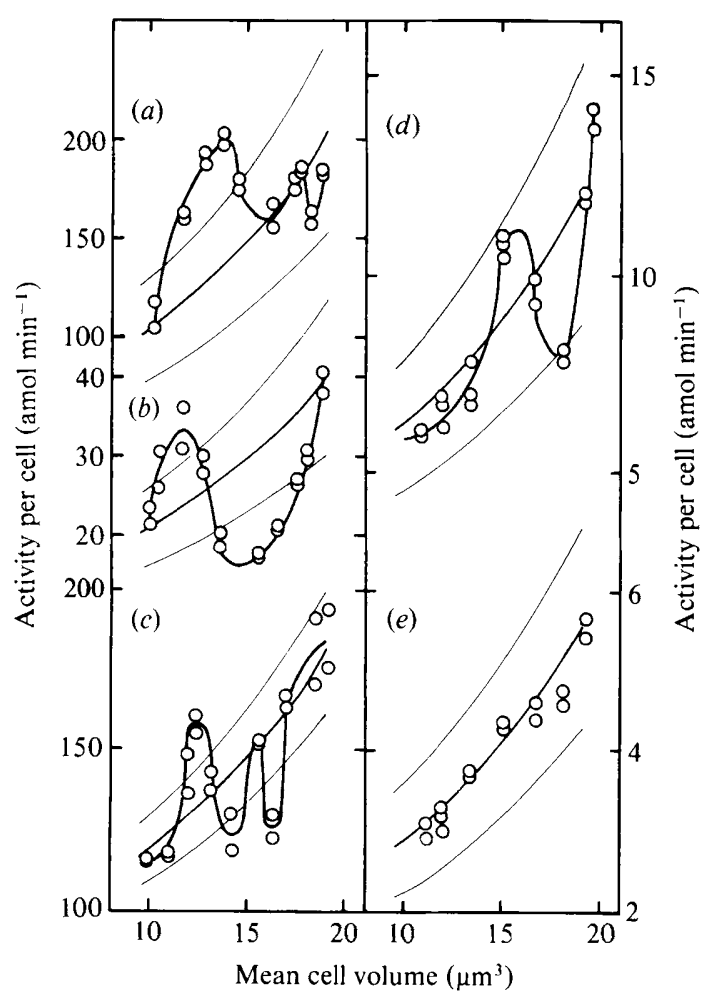

Fig. 1. Changes in enzyme activities in cell-free extracts prepared at successive stages of the cell cycle of $S$. halophilus. The enzymes assayed were $(a)$ NADH dehydrogenase, $(b)$ succinate dehydrogenase, $(c)$ cytochrome $c$ oxidase, $(d)$ catalase and $(e)$ acid phosphatase. The central bold line of each family of three smooth curves through the sets of experimental data represents an exponential rate of increase in activity that doubles during the cell cycle (i.e. between mean cell volumes of $9 \cdot 5$ and $19 \mu \mathrm{m}^{3}$ ). This line is the null hypothesis. The curves above and below this line indicate the extent of two standard deviations from this theoretical curve. The chance of any point lying outside this range is 1 in 20 , if the null hypothesis is valid. Enzyme activities are expressed as either amol substrate consumed $\mathrm{min}^{-1}$ per cell or as amol product produced $\min ^{-1}$ per cell.

stages in the cell cycle (Salmon \& Poole, 1983). Extracts of these fractions were prepared and assayed for several enzyme activities. Three mitochondrial enzymes, NADH dehydrogenase, succinate dehydrogenase and cytochrome $c$ oxidase showed an overall doubling in activity on a per cell basis (Fig. $1 a, b, c$ ). However, all these enzymes showed a discontinuous pattern of activity, which was significantly different $(95 \%$ level) from an exponential rate of increase (the null hypothesis), as can be judged from the disparity of the experimental data from the theoretical curve. In each case, several experimental points lay outside two standard deviations from the hypothesis (Fig. $1 a, b, c$ ).

Two maxima in activity were observed for cytochrome $c$ oxidase (Fig. $1 c$ ); the first occurred in fractions containing cells with a mean cell volume of about $12.5 \mu \mathrm{m}^{3}$, and the second in cells of about $15.5 \mu \mathrm{m}^{3}$. Note that the latter is indicated by $t w o$ datum points and that a maximum at this cycle stage was consistently observed in seven experiments (see Fig. $4 c$ ). In contrast, both NADH dehydrogenase (Fig. $1 a$ ) and succinate dehydrogenase (Fig. 1 b) displayed a single oscillation per cycle, though with the maxima in activities occurring in cells of different volumes. For NADH dehydrogenase, the maximum was in fractions containing cells with a mean volume of $13.5 \mu \mathrm{m}^{3}$, and for succinate dehydrogenase in cells of about $11.5 \mu \mathrm{m}^{3}$.

Catalase (a marker enzyme for peroxisomes) and acid phosphatase (a marker enzyme for lysosomes) (Lloyd \& Cartledge, 1974) also showed an overall doubling in activity on a per cell basis with respect to cell volume (Fig. $1 d, e$ ). Catalase showed an oscillatory pattern of activity 


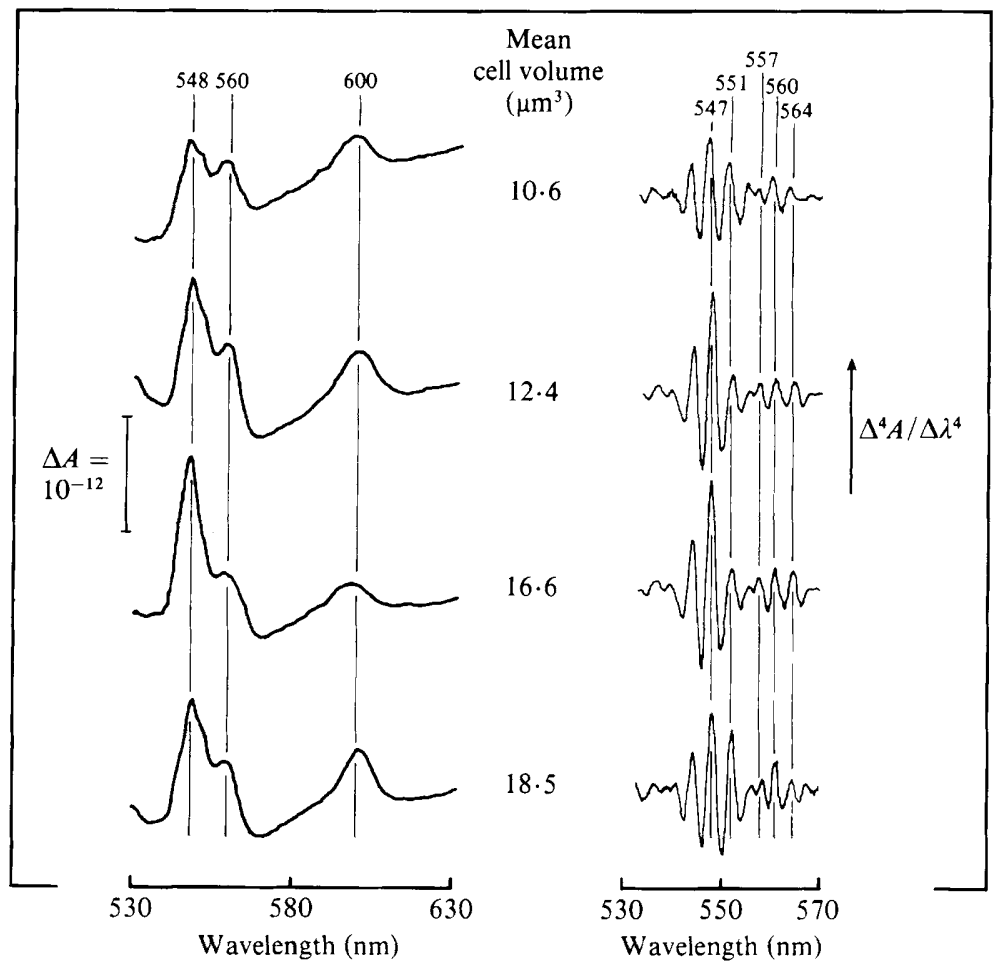

Fig. 2. Representative difference spectra and their respective fourth-order finite difference analyses. Each of the spectra on the left of the Figure is the sum of six replicate reduced $\left(\mathrm{NaBH}_{4}\right)$ minus oxidized $\left(\mathrm{H}_{2} \mathrm{O}_{2}\right)$ difference spectra, recorded at $77 \mathrm{~K}$ and a scan speed of $0.2 \mathrm{~nm} \mathrm{~s}^{-1}$ using a bandwidth of $1.0 \mathrm{~nm}$. Cell concentrations in each case were about $10^{10}$ cells ml $\mathrm{m}^{-1}$ but the spectra shown are scaled to a per cell basis. The mean cell volume in each gradient fraction shown is in the centre of the Figure. The fourth-order finite difference analysis (right) of each spectrum was calculated using differencing intervals of $1.8,1.4,1.2$ and $1.0 \mathrm{~nm}$.

with a single peak occurring in cells with a mean cell volume of about $15.5 \mu \mathrm{m}^{3}$ (Fig. $1 d$ ). Acid phosphatase, unlike the other enzymes, showed a continuous pattern of activity, which was consistent with an exponential rate of increase (Fig. 1e).

\section{Cellular content of cytochromes during the cell cycle}

The cytochrome content in cells of different size classes, obtained from zonal isopycnic separations, was determined in low-temperature difference $\left(\mathrm{NaBH}_{4}\right.$-reduced minus $\mathrm{H}_{2} \mathrm{O}_{2}$ oxidized) spectra. The contributions of the individual components to the composite $\alpha$-band of $b$ and $c$-type cytochromes were estimated from the bands revealed by fourth-order finite difference analysis of these spectra. This is illustrated in Fig. 2, which shows, for four representative cell cycle fractions, the spectra and their numerical analyses. The positions of the absorption maxima at about 544, 547, 551, 555, 557, 560 and $564 \mathrm{~nm}$ in the numerical analyses (Fig. 2) correspond closely to those observed previously for mitochondrial particles prepared from this organism (Salmon \& Poole, 1980a). On the basis of differential reduction and by comparison with the results of other workers, Salmon \& Poole (1980a) assigned the maxima at 548 and $554 \mathrm{~nm}$ to the $\alpha_{1}$ - and $\alpha_{2}$-bands, respectively, of cytochrome $c$, that at $551 \mathrm{~nm}$ to cytochrome $c_{1}$ and those at 554, 557, 560 and $563 \mathrm{~nm}$ to $b$-type cytochromes. The unfavourable signal-to-noise ratios in the $\alpha$-band region of cytochromes $a a_{3}$ precluded the numerical analysis of this absorption.

The variations across the gradient in the intensities of bands absorbing at about 547, 551, 557, 560 and 563 to $564 \mathrm{~nm}$ in the fourth-order finite difference spectra, and $600 \mathrm{~nm}$ in the difference 


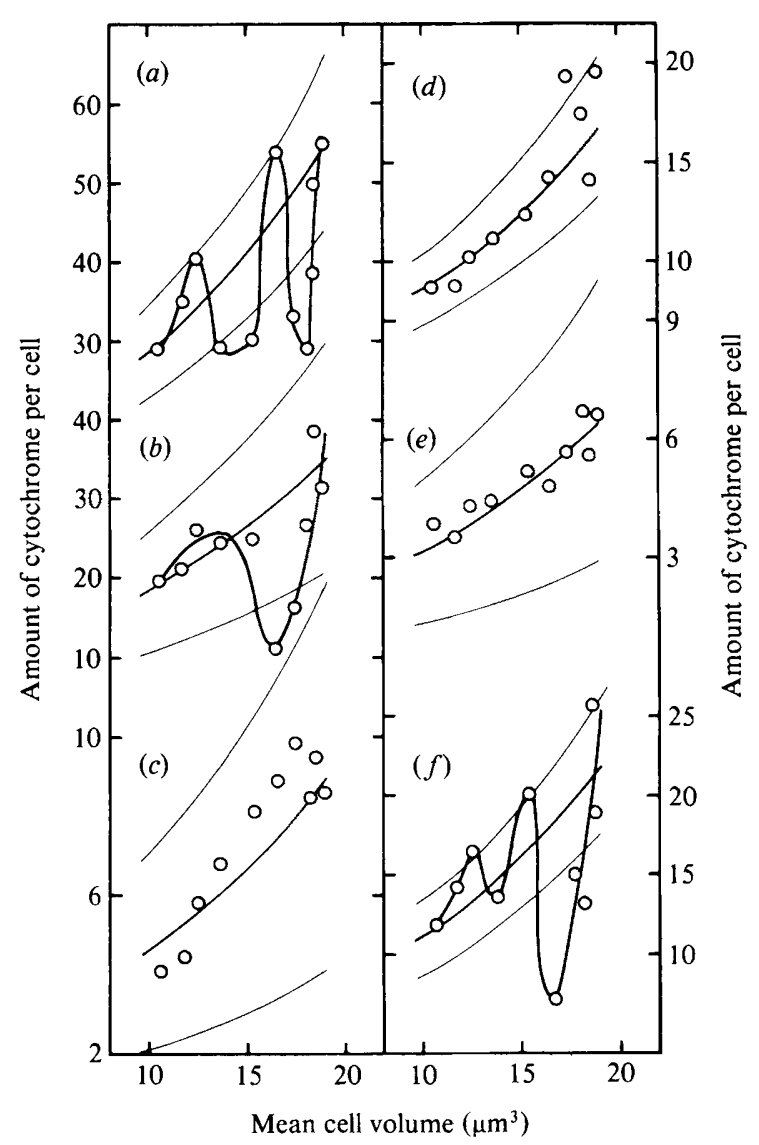

Fig. 3. Cellular content of cytochromes during the cell cycle of $S$. halophilus. Low temperature (77 K) reduced minus oxidized difference spectra were obtained of different size classes of cells, after isopycnic fractionation of an exponentially growing culture. Spectral conditions and the computation of fourthorder finite difference analyses were as described in Fig. 2. (a) Cytochrome $c,(b)$ cytochrome $c_{1}$, and $(c$, $d, e)$ three $b$-type cytochromes were estimated from the intensities of maxima in such analyses at 547 , $551,557,560$ and $563 \mathrm{~nm}$, respectively. The amount of cytochrome $a a_{3}(f)$ was determined from the height of the $600 \mathrm{~nm}$ absorbance in unanalysed difference spectra. The families of three curves for each cytochrome have the same meaning as in Fig. 1. Cytochrome amounts are expressed in arbitrary units per cell.

spectra, are shown in Fig. 3. The $b$-type cytochromes, represented by the absorptions at about 557,560 and $564 \mathrm{~nm}$ (Fig. $3 c, d$, $e$ respectively) all showed continuous patterns of accumulation, which were compatible with the null hypothesis (of exponential rate of increase during the cell cycle). However, the amounts of $c$-type cytochromes, measured from the absorptions at $547 \mathrm{~nm}$ (the $\alpha_{1}$-band of cytochrome $c$ ) and at $551 \mathrm{~nm}$ (the $\alpha$-band of cytochrome $c_{1}$ ), and of the $a$-type cytochromes measured from the intensity of the absorption at $600 \mathrm{~nm}$ (composite $\alpha$-band of cytochromes $a$ and $a_{3}$ ) did not give satisfactory fits to the null hypothesis, showing oscillatory patterns. Cytochrome $c$ (Fig. $3 a$ ) showed two maxima in amount during the cell cycle; the first occurred in cells with a mean volume of about $12.5 \mu \mathrm{m}^{3}$, and the second in cells of about $16.5 \mu \mathrm{m}^{3}$. Cytochrome $a a_{3}$ also showed two maxima in amount per cycle, which occurred in cells of similar sizes $\left(12.5 \mu \mathrm{m}^{3}\right.$ and $15.5 \mu \mathrm{m}^{3}$, Fig. $\left.3 f\right)$. Cytochrome $c_{1}$ showed a single broad peak with its maximum in cells with a mean volume of about $13.5 \mu \mathrm{m}^{3}$ (Fig. $3 b$ ). All these cytochromes showed an overall doubling in amount on a per cell basis during the cell cycle (Fig. 3).

The intensity of the absorption at $544 \mathrm{~nm}$ varied exactly in phase with that at $547 \mathrm{~nm}$ (results not shown) and displayed a constant stoichiometry of $0.62 \pm 0.05$ (S.D. in 27 independent 
(a)

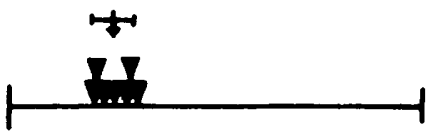

(b)

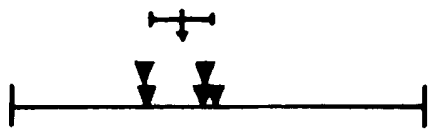

(c)

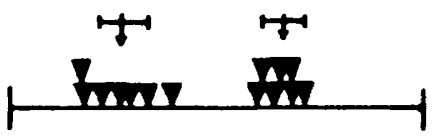

(d)

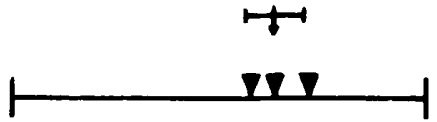

(e)

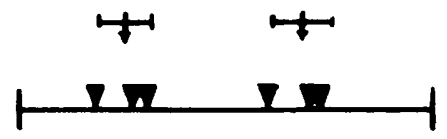

(f)

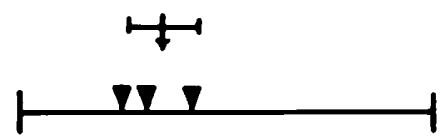

(g)

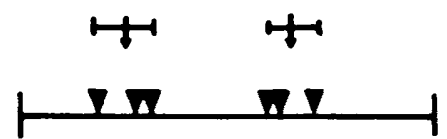

Fig. 4. Cell cycle maps indicating the timings of maxima of the activities of $(a)$ succinate dehydrogenase, $(b)$ NADH dehydrogenase, $(c)$ cytochrome oxidase and $(d)$ catalase, and of amounts of cytochrome (per cell) of $(e)$ cytochrome $c,(f)$ cytochrome $c_{1}$ and $(g)$ cytochrome $a a_{3}$, during the cell cycle of $S$. halophilus. It was assumed that cell age was directly proportional to mean cell volume over the range 9.5 to $19 \mu \mathrm{m}^{3}$. The arrows with bar lines indicate the mean and standard deviation of the timing of each maximum.

measurements in cells of different sizes) to the absorption at $547 \mathrm{~nm}$. This is further evidence for these two peaks belonging to the spectrum of a single component. Due to the low intensity of the peak at $554 \mathrm{~nm}$ and the consequent difficulty in resolving it (as can be judged from the high coefficient of variation of 0.70 obtained), no attempt was made to measure this.

The positions of the maxima in enzyme activities and in cytochrome amounts found in several measurements are shown in Fig. 4. In an analysis of variance of this data, the timings of the maxima in NADH dehydrogenase, succinate dehydrogenase and catalase activities were significantly different $(95 \%$ level) from one another. The timings of the first maximum in cytochrome $c$ oxidase activity were coincident with the maximum in succinate dehydrogenase, and the second with the maximum in catalase activity.

\section{DISCUSSION}

A major problem in interpretation of the changes in levels of cellular constituents that occur during the cell cycle is that all methods of cell cycle analysis give, at best, samples that are only enriched in cells of a particular age, size or density and which do not constitute truly homogeneous populations. In the present paper and in Salmon \& Poole (1983), the culture fractionation procedure was of high resolution, as judged by the coefficients of variation of sizes in the separated fractions, but each fraction will contain very few, if any, cells whose size is unique to that fraction, and cells of the same size will be found in adjacent fractions. Thus, the difference in enzyme or cytochrome level can only be due to a small fraction of the total cells whose mean size is different. This means that variations in levels in an individual cell through the cycle will be greater than those seen in Figs 1 and 3. In culture fractionations of the kind reported here, the failure of the dispersion of cell ages to obscure oscillatory patterns cannot be attributed to a dispersion or desynchronizing event late in the cycle as suggested by Lloyd et al. $(1982 b)$ to explain high amplitude oscillations in imperfectly synchronized cultures of Acanthamoeba castellanii. It is conceivable, however, that (1) synergistic phenomena ('self- 
synchronization') operate in the concentrated cell cycle fractions to enhance the oscillations, as occurs in high frequency glycolytic oscillations (Aldridge \& Pye, 1976), and (2) that Coulter measurements of volume distributions in the absence of hydrodynamic focusing devices overestimate the skewness of the size distributions (e.g. Roberts, 1980).

Of the five enzyme activities measured in this study, only one, that of acid phosphatase, increased continuously, in parallel with total protein (Salmon \& Poole, 1983), during the cell cycle of $S$. halophilus. Although various post-translational controls, such as conformational changes, covalent modifications and interaction with endogenous inhibitors may be invoked to explain cell cycle-dependent changes in activity (for a survey see Lloyd et al., 1982a), spectroscopic measurements of cytochrome levels in intact cells have revealed that periodic synthesis and/or degradation of the holoenzymes is involved. No conclusions may be drawn, however, regarding the cytochrome apoproteins since, in a variety of experimental systems, removal of the metal centre from redox-active metal-containing proteins results in loss of spectral features. For example, copper-limited growth of Neurospora crassa (Werner et al., 1974) or Candida utilis (Keyhani \& Chance, 1971) causes disappearance of spectrally detectable cytochrome $a a_{3}$. In both organisms, however, cytochrome apoproteins are detectable immunologically and, in $C$. utilis, porphyrin $a$ is also present in the apo-oxidase (Keyhani \& Keyhani, 1980). Such apocytochromes may be membrane-bound (Hennig \& Neupert, 1981). These studies identify diverse levels of control in the biosynthetic pathway of functional cytochromes, in addition to post-transcriptional and post-translational controls over protein synthesis.

Periodic modification and/or degradation of continuously synthesized proteins (Halvorson, 1977 ) is frequently discounted as an explanation of cell cycle-dependent changes in enzyme levels because estimates of protein turnover rates in exponentially growing cultures are low. However, these measurements have been criticized by Bakalkin et al. (1978) for not allowing adequately for post-incorporation and recycling of isotope label: the half-life of the products of mitochondrial translation in yeast was estimated as less than one hour by these authors. Even if the overall protein turnover rate is low, a small number of proteins may still be rapidly degraded. Thurston \& Richards (1980) have demonstrated that, in growing cells of Chlorella fusca, about $5 \%$ of the total protein has a much greater rate of turnover (about $20 \% \mathrm{~h}^{-1}$ ) than the overall rate of degradation, which is not more than $2 \cdot 1 \% \mathrm{~h}^{-1}$ (Richards \& Thurston, 1980).

Gear et al. (1974) and Rajwade et al. (1975) have suggested that proteases control both the quantity and composition of mitochondria by regulating the rates of turnover of mitochondrial proteins. Several proteolytic systems (e.g. Hare, 1978; Duque-Magalhāes \& Ferreira, 1980) have been identified in mitochondria. A protease with rapid turnover, responsible for the degradation in cytochrome $c$ oxidase of the higher molecular weight subunits that contain the haems and copper atoms (Winter et al., 1980), has been identified in $N$. crassa (Kumar \& Padmanaban, 1981). Luzikov et al. (1976) and Galkin et al. (1979) have demonstrated that the addition of specific inhibitors of protease to the culture medium of Saccharomyces cerevisiae prevents the changes in cytochrome content normally observed during growth. The results of the present study suggest that these proteolytic activities could be temporally, as well as spatially, organized.

For the complex composite spectra of mitochondrial cytochromes, the resolving power of fourth-order finite difference analysis was required (for a recent application, see Joergensen, 1981). Such spectra allowed the accurate measurements of the relative band intensities. The only assumptions that were made in this analysis were that the bandwidths and band shapes remained constant throughout the cell cycle (for a discussion of the influence of these parameters on derivative spectra, see Morrey, 1968).

The amounts of $b$-type cytochromes all increased continuously but both the $c$ - and $a$-type cytochromes displayed oscillations in amount during the cell cycle (Fig. 3). Cytochrome $c$ and cytochrome $a a_{3}$ oscillated in phase, with two maxima in amounts per cell cycle. The positions of these maxima in the cell cycle coincided with those of cytochrome $c$ oxidase activity. Since cytochrome $a a_{3}$ is the structural counterpart of the measured cytochrome $c$ oxidase activity, then at least for this enzyme the variation in activity actually reflected a variation in enzyme amount. In contrast, Cottrell et al. (1975) observed a stepwise increase in oxidase activity but a 
continuous increase in spectroscopically detectable oxidase in synchronous cultures of Sacch. cerevisiae prepared by an induction method. All the cytochromes that showed an oscillatory pattern of synthesis in the present study are of positive redox potential, and the last two components of the respiratory chain (cytochrome $c$ and cytochrome $a a_{3}$ ) oscillated in phase, perhaps indicating a common regulatory mechanism. However, cytochromes $c$ and $c_{1}$ are both coded for entirely by nuclear genes and cytochrome $a a_{3}$ in part by mitochondrial genes (for references, see Winter et al., 1980). Further work is required to study the turnover of individual subunits and their association with iron and copper, and to explain the coordinated degradation of cytochromes that are buried in the hydrophobic membrane core (e.g. cytochrome $c$ oxidase) or are peripherally associated with the matrix side of the mitochondrial inner membrane.

I.S. held an SERC Research Studentship during the course of this work. We thank Professor J. M. Mitchison for helpful comments and Dr P. T. Saunders for advice on statistics. The BXIV zonal rotor was purchased with funds from the University of London Central Research Fund.

\section{REFERENCES}

Aldridge, J. \& Pye, E. K. (1976). Cell density dependence of oscillatory metabolism. Nature, London 259, 670-671.

ARrigoni, O. \& Singer, T. P. (1962). Limitations of the phenazine methosulphate assay for succinic acid and related dehydrogenases. Nature, London 193, $1256-1258$.

Bakalkin, G. Y., Kalnov, S. L., Galkin, A. V., Zubatov, A. S. \& Luzikov, V. N. (1978). The lability of the products of mitochondrial protein synthesis in Saccharomyces cerevisiae. A novel method for protein half-life determination. Biochemical Journal 170, 569-576.

Cottrell, S. F., Rabinowitz, M. \& Getz, G. S. (1975). Cytochrome synthesis in synchronous cultures of the yeast, Saccharomyces cerevisiae. Journal of Biological Chemistry, 250, 4087-4094.

Duque-Magalhäes, M. C. \& Ferreira, M. M. M. (1980). Cytochrome $c$ degrading activity in rat liver mitochondria. Biochemical and Biophysical Research Communications 93, 106-112.

Edwards, S. W., Evans, J. B. \& Lloyd, D. (1981). Oscillatory accumulation of catalase during the cell cycle of Acanthamoeba castellanii. Journal of General Microbiology 125, 459-462.

Elliott, S. G. \& McLaughlin, C. S. (1978). Rate of macromolecular synthesis through the cell cycle of the yeast Saccharomyces cerevisiae. Proceedings of the National Academy of Sciences of the United States of America 75, 4384-4388.

Galkin, A. V., Tsoi, T. V. \& Luzikov, V. N. (1979). Regulation of mitochondrial biogenesis: further evidence for proteinase involvement. FEBS Letters 105, 373-375.

Gear, A. R. L., Albert, A. D. \& Bedwarek, J. M. (1974). The effect of the hypocholesterolemic drug clofibrate on liver mitochondrial biogenesis. A role for neutral mitochondrial proteases. Journal of Biological Chemistry 249, 6495-6504.

Haívorson, H. O. (1977). The cell division cycle. In Cell Differentiation in Microorganisms, Plants and Animals, pp. 361-376. Edited by L. Nover \& K. Mothes. Amsterdam: North Holland Publishing Co.

HARE, J. F. (1978). A novel proteinase associated with mitochondrial membranes. Biochemical and Biophysical Research Communications 83, 1206-1215.
HeNNig. B. \& NeUPERT, W. (1981). Assembly of cytochrome $c$. Apocytochrome $c$ is bound to specific sites on mitochondria before its conversion to holocytochrome $c$. European Journal of Biochemistry 121, 203-212.

von J AGOW, G., Weiss, H. \& KLingenberG, M. (1973). Comparison of the respiratory chain of Neurospora crassa wild-type and the mi-mutants mi-1 and mi-3. European Journal of Biochemistry 33, 140157.

JOERGENSEN, L. (1981). Identification of mitochondrial cytochromes of Tubifex sp. using fourth-order finite difference analysis of low temperature spectra. Comparative Biochemistry and Physiology 69B, 769774.

Keyhani, E. \& Chance, B. (1971). Cytochrome biosynthesis under copper-limited conditions in Candida utilis. FEBS Letters 17, 127-132.

KEYHANI, E. \& KeYHANI, J. (1980). Identification of porphyrin present in apo-cytochrome $c$ oxidase of copper-deficient yeast cells. Biochimica et biophysica acta 633, 211-227.

Kumar, C. C. \& Padmanaban, G. (1981). Evidence for the involvement of a rapidly turning-over protease in the degradation of cytochrome oxidase in Neurospora crassa. Biochemical and Biophysical Research Communications 100, 576-583.

Lloyd, D. \& CARTledge, T. G. (1974). Marker enzymes of eukaryotic micro-organisms. In Methodological Developments in Biochemistry, Vol. 4, Subcellular Studies, pp. 339-346. Edited by E. Reid. London: Longman.

Lloyd, D., Poole, R. K. \& Edwards, S. W. (1982a). The Cell Division Cycle: Temporal Organization and Control of Cellular Growth and Reproduction. London: Academic Press.

Lloyd, D., Edwards, S. W. \& Fry, J. C. (1982b). Temperature-compensated oscillations in respiration and cellular protein content in synchronous cultures of Acanthamoeba castellanii. Proceedings of the National Academy of Sciences of the United States of America 79, 3785-3788.

Lück, H. (1963). Catalase. In Methods in Enzyme Analysis, pp. 885-894. Edited by H. U. Bergmeyer. New York: Academic Press.

Luzikov, V. N., Makhlis, T. A. \& Galkin, A. V. 
(1976). A probable role of cell proteinases in the biogenesis of mitochondria in yeast. FEBS Letters 69, 108-110.

MAHLER, H. R. (1955). DPNH cytochrome $c$ reductase (animal). Methods in Enzymology 2, 688-693.

Milner, H. W., Lawrence, N. S. \& French, C. S. (1950). Colloidal dispersion of chloroplast material. Science 111, 633-634.

MORREY, J. R. (1968). On determining spectral peak positions from composite spectra with a digital computer. Analytical Chemistry 40, 905-914.

Poole, R. K. \& Lloyd, D. (1973). Oscillations of enzyme activities during the cell cycle of a glucoserepressed fission yeast Schizosaccharomyces pombe $972 \mathrm{~h}^{-}$. Biochemical Journal 136, 195-207.

Poole, R. K. \& LloYd, D. (1974). Changes in respiratory activities during the cell cycle of the fission yeast Schizosaccharomyces pombe $972 \mathrm{~h}^{-}$ growing in the presence of glycerol. Biochemical Journal 144, 141-148.

Poole, R. K., Lloyd, D. \& Chance, B. (1974). The development of cytochromes during the cell cycle of a glucose-repressed fission yeast Schizosaccharomyces pombe $972 \mathrm{~h}^{-}$. Biochemical Journal 138, 201210.

Rajwade, M. S., Katyare, S. S., Fatterpaker, P. \& SReENIVASAN, A. (1975). Regulation of mitochondrial protein turnover by thyroid hormone(s). Biochemical Journal 152, 379-387.

REJ, R. \& RICHARDS, A. H. (1974). Interference by Tris buffer in the estimation of protein by the Lowry procedure. Analytical Biochemistry 62, 240-247.

Richards, L. \& Thurston, C. F. (1980). Protein turnover in Chlorella fusca var. vacuolata: measurement of the overall rate of intracellular protein degradation using isotope exchange with water. Journal of General Microbiology 121, 49-61.

ROBERTS, D. MCL. (1980). Aspects of cell size measurement in Tetrahymena elliotti. Journal of General Microbiology 120, 211-218.
SAlmon, I. \& PoOLE, R. K. (1980a). The mitochondrial cytochromes of an unusual budding yeast, Sterigmatomyces halophilus : spectral characterization exploiting fourth-order finite difference analysis. Journal of General Microbiology 117, 315-326.

Salmon, I. \& PoOle, R. K. (1980 b). Activities of some mitochondrial enzymes in the cell cycle of Sterigmatomyces halophilus. Society for General Microbiology Quarterly 7, 85.

Salmon, I. \& Poole, R. K. (1983). The cell cycle of the budding yeast Sterigmatomyces halophilus: culture fractionation by zonal centrifugation and the accumulation of DNA, RNA and protein. Journal of General Microbiology 129, 2129-2141.

Singer, T. P., Kearney, E. B. \& Kenney, W. C. (1973). Succinate dehydrogenase. Advances in Enzymology 37, 189-272.

SMITH, L. (1955). Cytochromes $a, a_{1}, a_{2}$ and $a_{3}$. Methods in Enzymology 2, 732-740.

Thurston, C. F. \& Richards, L. (1980). Protein turnover in Chlorella fusca var. vacuolata: detection of a rapidly degraded class of protein in growing and non-growing cells. Journal of General Microbiology 121, 63-68.

TORRIANI, A. (1960). Influence of inorganic phosphate in the formation of phosphatase by Escherichia coli. Biochimica et biophysica acta 38, 460-469.

Werner, S., SchWAB, A. J. \& NeUPERT, W. (1974). Precursors of cytochrome oxidase in cytochromeoxidase-deficient cells of Neurospora crassa. Comparison of the nuclear mutant $c n i-1$, the cytoplasmic mutant $m i-1$ and copper-depleted wild-type. European Journal of Biochemistry 49, 607-617.

Winter, D. B., BruYNinckX, W. S., Foulke, F. G., Grinich, N. P. \& Mason, H. S. (1980). Location of heme $a$ on subunits I and II and copper on subunit II of cytochrome $c$ oxidase. Journal of Biological Chemistry 255, 11408-11414. 